\title{
Erratum to: An Alternative Approach to Ethical HRM Through the Discourse and Lived Experiences of HR Professionals
}

\author{
Nadia de Gama • Steve McKenna • \\ Amanda Peticca-Harris
}

Published online: 10 November 2012

(C) Springer Science+Business Media Dordrecht 2012

\section{Erratum to: J Bus Ethics}

DOI 10.1007/s10551-012-1479-z

The above mentioned article was accepted as 'An alternative approach to ethical HRM through the discourse and lived experiences of HR professionals'. During proof stage the title was changed to 'Ethics and HRM: Theoretical and
Conceptual Analysis; An Alternative Approach to Ethical HRM Through the Discourse and Lived Experiences of HR Professionals' without approval of the guest editors.

The original title 'An alternative approach to ethical $H R M$ through the discourse and lived experiences of $H R$ professionals' it to be used when referring to this article in other works.

The online version of the original article can be found under doi:10.1007/s10551-012-1479-z.

N. de Gama $\cdot$ S. McKenna $(\varangle) \cdot$ A. Peticca-Harris

School of Human Resources Management, York University,

Toronto, ON M3J 1P3, Canada

e-mail: smckenna@yorku.ca 